\title{
PENGARUH PELATIHAN DOWN THE LINE DRILL TERHADAP KELINCAHAN DAN POWER OTOT TUNGKAI
}

\author{
I Pt Agus Hendrawan, I Ketut Sudiana, Ni Putu Dewi Sri Wahyuni \\ Jurusan IImu Keolahragaan, FOK \\ Universitas Pendidikan Ganesha \\ Singaraja, Indonesia \\ e-mail:\{agushendrawan873@yahoo.co.id, sudiana_67@yahoo.co.id,Putudewisri@gmail.com
}

\begin{abstract}
Abstrak
Penelitian ini bertujuan untuk mengetahui pengaruh pelatihan down the line drill terhadap kelincahan dan power otot tungkai pada siswa putra kelas VII SMP Negeri 2 Sawan tahun 2014. Jenis penelitian adalah eksperimen sungguhan dengan rancangan "The randomized pretest-posttest control group design". Sampel penelitian ini siswa putra kelas VII jumlah 32. Instrumen yang digunakan dalam penelitian ini zig-zag run untuk kelincahan dan standing broad jump untuk power otot tungkai. Data dianalisis dengan uji-t independent pada taraf signifikansi $(\square)$ 0,05 dengan SPSS 16. Dengan menggunakan uji-t independent untuk data kelincahan diperoleh nilai signifikansi hitung lebih kecil dari nilai $\alpha($ Sig $<0,05)$ yaitu sebesar 0,02. Sedangkan untuk data power otot tungkai diperoleh nilai signifikansi hitung lebih kecil dari nilai a $(\mathrm{Sig}<0,05)$ yaitu sebesar 0,00 . Sehingga dapat disimpulkan bahwa pelatihan down the line drill berpengaruh terhadap peningkatan kelincahan dan power otot tungkai pada siswa putra kelas VII SMP Negeri 2 Sawan tahun 2014.
\end{abstract}

Kata-kata kunci: pelatihan down the line drill, kelincahan, power otot tungkai

\begin{abstract}
This study aims to determine the effect of training down the line drill on agility and leg muscle power in men's class VII student of SMP Negeri 2 Sawan 2014. This type of research is to design a real experiment "The randomized pretest-posttest control group". The sample of this study male student of class VII number 32. The instrument used in this study zigzagging run for agility and astanding broad jump for leg muscle power. Data were analyzed by independent t-test at the significance level $(\alpha) 0.05$ with SPSS 16.0. Based on the data analysis of this study, using independent $t$-test to the data obtained agility significance count value is smaller than the value of a $(\mathrm{Sig}<0.05)$ that is equal to 0.02 . As for the leg muscle power of data obtained significance count value is smaller than the value of a (Sig <0.05) that is equal to 0.00 . Thus, the research hypothesis of training down the line drill to increase agility and leg muscle power, is acceptable. From the results of this study concluded that training down the line drill affect the increased agility and leg muscle power in the seventh grade male student SMP Negeri 2 Sawan 2014.
\end{abstract}

Key words: training down the line drill, agility, leg muscle power 


\section{PENDAHULUAN}

Olahraga adalah suatu bentuk aktivitas fisik yang terencana dan terstruktur yang melibatkan gerakan tubuh berulang-ulang. Dalam olahraga ada empat dasar yang menjadi tujuan manusia dalam melakukan olahraga. Pertama, manusia berolahraga hanya untuk rekreasi seperti outbond. Kedua, manusia berolahraga dengan tujuan pendidikan. Ketiga, manusia melakukan kegiatan olahraga untuk penyembuhan suatu penyakit dan pemulihan kesehatan atau rehabilitasi. Keempat, manusia melakukan olahraga untuk mencapai suatu prestasi. Bagi para atlet, prestasi olahraga adalah tujuan akhir dari segala usaha yang dilakukan atlet. Jadi prestasi olahraga adalah hasil kerja fisik yang dicapai sesuai dengan cabang olahraga dan dipengaruhi oleh faktor-faktor.

SMP Negeri 2 Sawan sebuah lembaga pendidikan yang terletak di Desa Bungkulan, Kecamatan Sawan. Para siswa SMP Negeri 2 Sawan sering ikut serta dalam beberapa pertandingan/kejuaraan sepak bola yang diadakan baik itu dalam tingkat Kecamatan, bahkan ditingkat Kabupaten. Dari hasil wawancara peneliti dengan guru olahraga di SMP Negeri 2 Sawan, menemukan masalah dari prestasi siswa SMP Negeri 2 Sawan dalam cabang olahraga sepak bola yang mengalami penurunan. $\mathrm{Hal}$ ini terbukti dengan menurunnya perolehan juara pada sepak bola pada saat pekan olahraga pelajar berlangsung. Penurunan ini terjadi pada saat pekan olahraga dan seni pelajar tahun 2011, pada pekan olahraga dan seni pelajar sebelumnya cabang olahraga sepak bola mendapat peringkat kedua di tingkat Kabupaten, sedangkan pada tahun 2012 hanya memperoleh peringkat ke empat. Penurunan prestasi siswa ini disebabkan oleh kurangnya pembinaan kondisi fisik. Pelatihan fisik yang diberikan masih umum dan monoton yang mengakibatkan kejenuhan pada siswa. Hal tersebut secara tidak langsung berdampak pada penurunan prestasi olahraga di SMP Negeri 2 Sawan. "Untuk meningkatan prestasi seorang atlet, maka diperlukan berbagai macam pembinaan kondisi fisik. Pembinaan kondisi fisik merupakan pembinaan awal dan sebagai dasar pokok dalam mengikuti pelatihan olahraga untuk mencapai suatu prestasi" (Nala, 1998: 38).

Menyikapi hal tersebut peneliti perlu melakukan suatu solusi yang mampu meningkatkan kualitas olahraga di SMP Negeri 2 Sawan. "Salah satunya adalah memberikan pembinaan kemampuan fisik melalui pelatihan down the line drill. Down the line drill adalah bentuk pelatihan yang termasuk jenis pelatihan lari rintang (obstacle run)" (Nala 1998: 75). Dengan melompat dan berlari dengan cepat serta arah yang berubah-ubah, pelatihan ini 
memungkinkan untuk melatih komponen kelincahan dan power otot tungkai yang erat kaitannya dengan kecepatan, kekuatan, dan kemampuan merubah arah dengan cepat. Kelincahan dan power otot tungkai sangat penting dalam setiap cabang olahraga.

Hardiyanti (2013) dalam jurnal yang berjudul Efektifitas Latihan Hexagon Drill dan Zig-Zag Run Terhadap Kelincahan menunjukkan "hasil bahwa latihan hexagon drill dan zig-zag run berpengaruh pada peningkatan kelincahan atlet bulutangkis putri usia 10-12 tahun di PB. PWS dan PB. Pancing Sleman dimana latihan hexagon drill kurang efektif dibanding latihan zig-zag run dalam meningkatkan kelincahan atlet bulutangkis".

Himawan Wismanadi (2010) dalam jurnal yang berjudul Pengaruh Pelatihan Plyometrik Rim Jump Dan Hexagon Drill Terhadap Peningkatan Daya Ledak Otot Tungkai menunjukkan "hasil penelitian bahwa latihan plyometrik rim jump dan hexagon drill berpengaruh terhadap peningkatan daya ledak otot tungkai. Dimana bentuk pelatihan hexagon drill lebih baik dari pada pelatihan plyometrik rim jump".

\section{Rumusan Masalah Penelitian}

Berdasarkan latar belakang masalah di atas, maka dirumuskan permasalahan sebagai berikut :

1) Apakah pelatihan down the line drill berpengaruh terhadap kelincahan pada siswa putra kelas VII SMP Negeri 2 Sawan?

2) Apakah pelatihan down the line drill berpengaruh terhadap power otot tungkai pada siswa putra kelas VII SMP Negeri 2 Sawan?

ini adalah:
1. Untuk mengetahui pengaruh pelatihan down the line drill terhadap kelincahan pada siswa putra kelas VII SMP Negeri 2 Sawan.

2. Untuk mengetahui pengaruh pelatihan down the line drill terhadap power otot tungkai pada siswa putra kelas VII SMP Negeri 2 Sawan.

\section{METODE}

Dalam penelitian ini menggunakan penelitian eksperimen sungguhan, dengan rancangan Penelitian "The Randomized Pre-test Post-test Control Group Design" (Kanca I Nyoman, 2006:73). Sampel penelitian ini adalah siswa putra kelas VII SMP Negeri 2 Sawan tahun 2014 yang berjumlah 32 orang, kemudian diberikan pre-test untuk mengukur kelincahan dengan menggunakan tes zig-zag run dan untuk mengukur power otot tungkai dengan menggunakan vertical jump. Berdasarkan hasil tes, sampel dibagi menjadi 2 kelompok dengan teknik ordinal pairing yaitu Kelompok 1: kelompok perlakuan pelatihan down the line drill dan kelompok 2: kelompok kontrol (pelatihan konvensional) yaitu passing kontrol sepak bola. Setelah program pelatihan selesai, maka kedua kelompok diberikan post-test yang sama dengan test awal (pre-test). Teknik analisis data untuk uji normalitas sebaran data menggunakan instrument uji Lilliefors kolmogorov-smirnov dengan bantuan komputer program SPSS 16,0 pada taraf signifikansi ( $\alpha$ ) 0,05 . Untuk uji homogenitas varian data menggunakan analisis uji Lavene dengan bantuan komputer program SPSS 16,0 pada taraf signifikansi (a) 0,05. Sedangkan untuk uji hipotesis diuji dengan instrument uji-t independent ( $u j i$ t) dengan bantuan komputer program SPSS 16,0 pada taraf signifikansi ( $\alpha$ ) 0,05 . Tempat pelaksanaan dalam 
penelitian ini adalah SMP Negeri 2

Sawan. Penelitian dilaksanakan selama 4 minggu dengan frekuensi latihannya adalah 3 kali pertemuan dalam seminggu. Pelatihan dilaksanakan selama 3 kali dalam seminggu, yang bertujuan untuk memberikan kesempatan tubuh beradaptasi terhadap beban yang diberikan dalam pelatihan ini.

\section{HASIL DAN PEMBAHASAN}

Hasil

Data hasil penelitian kecepatan dan kelincahan dari data pre-test dan post-test. Data pre-test diambil pada awal kegiatan penelitian yaitu sebelum sampel penelitian diberikan perlakuan, sedangkan data post-test diambil pada akhir kegiatan penelitian yaitu setelah sampel penelitian diberikan perlakuan selama 12 kali pelatihan

Tabel 1. Data Hasil Penelitian Kelincahan

\begin{tabular}{lcccccc}
\hline \multirow{2}{*}{$\begin{array}{l}\text { Variabel } \\
\text { Data }\end{array}$} & \multicolumn{2}{c}{ Pretest } & \multicolumn{2}{c}{ Posttest } & \multicolumn{2}{c}{ Gain Score } \\
\cline { 2 - 7 } & Perlakuan & Kontrol & Perlakuan & Kontrol & Perlakuan & Kontrol \\
\hline Sampel & 16 & 16 & 16 & 16 & & \\
\hline Mean & 16,49 & 16,67 & 16,07 & 17,02 & 0,41 & $-0,34$ \\
\hline Median & 16,34 & 16,54 & 16,10 & 17,09 & 0,40 & $-0,32$ \\
\hline Modus & 15,56 & 15,75 & 16,10 & 15,54 & 0,11 & $-0,95$ \\
\hline Variance & 0,32 & 0,38 & 2,04 & 0,47 & 1,25 & 0,30 \\
\hline $\begin{array}{l}\text { Standar } \\
\text { deviation }\end{array}$ & 0,57 & 0,62 & 1,42 & 0,68 & 1,11 & 0,54 \\
\hline Minimum & 15,56 & 15,75 & 13,61 & 15,54 & $-2,17$ & $-1,42$ \\
\hline Maximum & 17,38 & 17,94 & 19,23 & 18,22 & 2,58 & 0,49 \\
\hline Range & 1,82 & 2,19 & 5,62 & 2,68 & 4,75 & 1,91 \\
\hline
\end{tabular}

\section{Pengujian}

terhadap

normalitas sebaran data penelitian dilakukan pada data beda (gain score) dari data kelincahan pada kelompok perlakuan pelatihan down the line drill dan kelompok kontrol yang menggunakan uji Lilliefors dengan bantuan komputer program SPSS 16,0 pada taraf signifikansi $(\alpha)$ 0,05 .

\section{Kriteria}

pengambilan keputusannya, yaitu jika signifikansi yang diperoleh $>\alpha$ ( $\mathrm{sig}>0,05)$, maka sampel berasal dari populasi yang berdistribusi normal. Sebaliknya, jika signifikansi yang diperoleh < $\alpha($ sig < 0,05), maka sampel bukan berasal dari populasi yang berdistribusi normal. 
Jurnal IImu Keolahragaan Undiksha

p-ISSN: 2613-9693 | e-ISSN: 2613-9685

Volume 6 Nomor 1 Tahun 2018

Tabel 2. Data Hasil Penelitian Power Otot Tungkai

\begin{tabular}{lcccccc}
\hline \multirow{2}{*}{$\begin{array}{l}\text { Variabel } \\
\text { Data }\end{array}$} & \multicolumn{2}{c}{ Pretest } & \multicolumn{2}{c}{ Posttest } & \multicolumn{2}{c}{ Gain Score } \\
\cline { 2 - 7 } & Perlakuan & Kontrol & Perlakuan & Kontrol & Perlakuan & Kontrol \\
\hline Sampel & 16 & 16 & 16 & 16 & & \\
\hline Mean & 1,60 & 1,56 & 2,14 & 1,31 & 0,54 & $-0,25$ \\
\hline Median & 1,60 & 1,54 & 2,09 & 1,18 & 0,56 & $-0,40$ \\
\hline Modus & 1,69 & 1,63 & 1,96 & 0,34 & $-0,76$ & $-1,20$ \\
\hline Variance & 0,01 & 0,02 & 0,94 & 0,35 & 0,94 & 0,36 \\
\hline $\begin{array}{l}\text { Standar } \\
\text { deviation }\end{array}$ & 0,11 & 0,14 & 0,97 & 0,59 & 0,97 & 0,60 \\
\hline Minimum & 1,37 & 1,28 & 0,73 & 0,34 & $-0,76$ & $-1,20$ \\
\hline Maximum & 1,78 & 1,80 & 4,20 & 2,23 & 2,46 & 0,75 \\
\hline Range & 0,41 & 0,52 & 3,47 & 1,89 & 3,22 & 1,95 \\
\hline
\end{tabular}

Pengujian terhadap normalitas sebaran data penelitian dilakukan pada data beda (gain score) dari data power otot tungkai pada kelompok perlakuan pelatihan down the line drill dan kelompok kontrol yang menggunakan uji Lilliefors dengan bantuan komputer program SPSS 16,0 pada taraf signifikansi $(\alpha) 0,05$.

Kriteria pengambilan keputusannya, yaitu jika signifikansi yang diperoleh $>\alpha$ (sig > 0,05), maka sampel berasal dari populasi yang berdistribusi normal. Sebaliknya, jika signifikansi yang diperoleh $<\alpha($ sig $<0,05)$, maka sampel bukan berasal dari populasi yang berdistribusi normal.

Berdasarkan hasil uji normalitas data menggunakan Uji lilliefors dengan bantuan SPSS 16. Untuk variabel keincahan kelompok perlakuan mendapatkan nilai statistik 0,14 dengan nilai signifikansi 0,20 dan dapat disimpulkan data berdistribusi normal. Untuk kelompok kontrol mendapatkan nilai statistic 0,13 dengan nilai signifikansi 0,20 dan dapat disimpulkan data berdistribusi normal. Untuk variabel power otot tungkai kelompok perlakuan mendapatkan nilai statistik 0,15 dengan nilai signifikansi 0,20 dan dapat disimpulkan data berdistribusi normal. Untuk kelompok kontrol mendapatkan nilai statistic 0,15 dengan nilai signifikansi 0,20 dan dapat disimpulkan data berdistribusi normal. Uji normalitas data dimaksudkan uji untuk mengukur apakah data kita memiliki distribusi normal sehingga dapat dipakai dalam statistik parametrik. Pengujian normalitas data dalam penelitian ini mempergunakan uji lilliefors dengan bantuan SPSS 16,0 pada taraf $\begin{array}{llll}\text { signifikansi } & (\alpha) & 0,05 & \text { Kreteria }\end{array}$ pengambilan keputusan yaitu jika nilai signifikansi yang diperoleh lebih besar dari pada $\alpha$ (sig $>\alpha$ ), maka sampel berasal dari populasi yang berdistribusi normal, sedangkan jika nilai signifikansi yang diperoleh lebih kecil dari pada a (sig < $\alpha$ ), maka sampel bukan berasal dari populasi yang berdistribusi normal. Dari hasil perhitungan semua nilai signifikansi yang diperoleh $>0,05$, dengan demikian data penelitian berdistribusi normal.

Uji homogenitas dimaksudkan untuk memperlihatkan bahwa dua atau lebih kelompok data berasal dari 
populasi yang memiliki Variancesi yang sama. Uji homogenitas data dalam penelitian ini adalah uji Levene dengan bantuan program SPSS 16,0 taraf signifikansi ( $\alpha$ ) 0,05. Kreteria pengambilan keputusan yaitu jika nilai signifikansi yang diperoleh > $\alpha$, maka Variancesi sampel adalah sama (homogen), sedangkan jika signifikansi yang diperoleh < a maka Variancesi setiap sampel tidak sama (tidak homogen). Dari hasil perhitungan semua nilai signifikansi yang diperoleh $>a$, sehingga data penelitian yang diuji berasal dari data dengan variasi homogen. Dari hasil uji levene maka diperoleh data untuk variabel kelincahan mendapatkan nilai statistik 2,85 dengan nilai signifikansi 0,10 dan dapat disimpulkan data berdistribusi homogen. Untuk variable power otot tungkai mendapatkan nilai statistik 2,76 dengan nilai signifikansi 0,10 dan dapat disimpulkan data berdistribusi homogen.

Dari hasil uji homogenitas data, dilakukan terhadap data gain score kelincahan dan power otot tungkai menggunakan instrumen uji Levene dengan bantuan program komputer SPSS 16,0 pada taraf signifikansi $(\alpha)$ 0,05 . Diperoleh nilai uji 2,76 dengan signifikansi 0,10 untuk variabel kelincahan, sedangkan pada variabel power otot tungkai diperoleh nilai uji 2,85 dengan signifikansi 0,10 . Dari hasil uji didapatkan nilai signifikansi hitung untuk kedua data tersebut lebih besar dari pada a (Sig $>0,05)$, dengan demikian data yang diuji berasal dari data dengan variansi homogen.

Uji hipotesis terdapat pengaruh pelatihan down the line drill terhadap kelincahan, menggunakan uji inferensial dengan uji-t independent. Hipotesis ini diuji menggunakan bantuan SPSS 16,0 pada taraf signifikansi $\alpha=0,05$. Kriteria pengambilan keputusan yaitu jika nilai signifikansi $\mathrm{t}_{\text {hitung }}<0,05$ berarti terdapat peningkatan yang signifikan dari perlakuan yang diberikan sedangkan jika nilai signifikansi $\mathrm{t}_{\text {hitung }}>0.05$ berarti tidak ada peningkatan yang signifikan dari perlakuan yang diberikan. Sesuai dengan perhitungan terdapat peningkatan yang signifikan karena nilai $\mathrm{t}_{\text {hitung }}$ lebih kecil dari 0,05. Dari hasil Uji-t Independent data kelincahan diperoleh nilai signifikansi hitung 0,02 .

Uji hipotesis terdapat pengaruh pelatihan down the line drill terhadap power otot tungkai, menggunakan uji inferensial dengan uji-t independent. Hipotesis ini diuji menggunakan bantuan SPSS 16,0 pada taraf signifikansi $\alpha=0,05$. Kriteria pengambilan keputusan yaitu jika nilai signifikansi $\mathrm{t}_{\text {hitung }}<0,05$ berarti terdapat peningkatan yang signifikan dari perlakuan yang diberikan sedangkan jika nilai signifikansi $\mathrm{t}_{\text {hitung }}>0.05$ berarti tidak ada peningkatan yang signifikan dari perlakuan yang diberikan. Sesuai dengan perhitungan terdapat peningkatan yang signifikan karena nilai $\mathrm{t}_{\text {hitung }}$ lebih kecil dari 0,05. . Dari hasil Uji-t Independent data power otot tungkai diperoleh nilai signifikansi hitung 0,00.

\section{Pembahasan}

Hasil analisis data hasil penelitian untuk variabel terikat penelitian menunjukan adanya peningkatan nilai rata-rata (mean) untuk masing-masing variabel. Dari deskripsi data variabel kelincahan seperti terlihat dari deskripsi data variabel kelincahan pada tabel 4.1 terlihat kelompok perlakuan mengalami peningkatan nilai ratarata. Nilai pre-test kelompok perlakuan memiliki rata-rata 16,49 dan rata-rata nilai post-test 16,07 , dengan demikian nilai rata-rata 
kelompok perlakuan meningkat 0,42.

Kelompok kontrol didapatkan nilai rata-rata sebesar -0.35 dari 16,67 pada saat pre-test menjadi 17,02 pada saat post-test.

Bentuk pelatihan perlakuan down the line drill yang dilakukan adalah pelatihan dengan frekuensi pelatihan adalah sebanyak 3 kali seminggu selama 4 minggu.

\section{Pelatihan Down The Line Drill Berpengaruh Terhadap Kelincahan}

Berdasarkan hasil uji-t independen untuk variabel kecepatan, antara gain score kelompok perlakuan dan kelompok kontrol didapatkan nilai $t_{\text {hitung }}=2,43$ dengan nilai signifikansi $=0,02$ pada taraf signifikansi 0,05 . Nilai signifikansi hitung lebih kecil dari nilai $\alpha($ Sig $<0,05)$, dengan demikian hipotesis penelitian pelatihan down the line drill yang signifikan berpengaruh terhadap kelincahan pada siswa putra kelas VII SMP Negeri 2 Sawan tahun 2014.

Secara teoritis, hasil penelitian pelatihan down the line drill berpengaruh terhadap peningkatan kelincahan,. Kelincahan merupakan kemampuan untuk mengubah posisi tubuh atau gerakan tubuh dengan cepat ketika sedang bergerak cepat, tanpa kehilangan keseimbangan atau kesadaran orientasi terhadap posisi tubuh (Nala 1998: 74).

Komponen kelincahan ini sudah termasuk unsur bergerak dengan cepat, mengubah posisi tubuh dengan cepat, bergerak lalu berhenti dan dilanjutkan dengan bergerak secepatnya. Kemampuan seperti ini membutuhkan komponen koordinasi yang prima. Koordinasi merupakan kemampuan tubuh untuk mengintegrasikan berbagai gerakan yang berbeda menjadi gerakan tunggal yang harmonis dan efektif (Nala, 1998: 10).

\section{Pelatihan Down The Line Drill Terhadap Power Otot Tungkai}

Berdasarkan hasil uji-t independen untuk variabel kelincahan, antara gain score kelompok perlakuan dan kelompok kontrol didapatkan nilai $t_{\text {hitung }}=2,78$ dengan nilai signifikansi $=0,00$ pada taraf signifikansi 0,05 . Nilai signifikansi hitung lebih kecil dari nilai $\alpha($ Sig < 0,05), dengan demikian hipotesis penelitian pelatihan down the line drill berpengaruh terhadap peningkatan power otot tungkai.

Power merupakan gabungan antara kelincahan dan kecepatan atau pengerahan gaya otot maximum dengan kecepatan maximum (Widiastuti 2011:16).

Power atau elastic strength sangat penting untuk cabangcabang olahraga seperti: sprint, lari gawang, nomor-nomor lempar dan lompat. Disamping itu, power juga perlu untuk memukul (tinju, softball, karate, dan lain-lain), menendang (pencak silat, kempo, dan lain-lain), membanting (gulat, judo, dan lainlain), dan mengangkat dengan cepat (gulat, angkat besi, dan lain-lain) (Yoda, Ketut, 2006:27). Power otot tungkai sangat penting untuk cabang olahraga yang memerlukan gerakan eksplosif yang ditandai dengan gerakan atau perubahan tiba-tiba yang cepat, di mana tubuh terdorong ke atas (vertikal) baik itu melompat maupun meloncat ke depan (horisontal) dengan mengerahkan kelincahan otot maksimal seperti cabang olahraga sepak bola. Sebagai salah satu komponenkomponen kondisi fisik, power otot tungkai dapat ditingkatkan melalui program-program pelatihan yang dirancang secara sistematis dan berkesinambungan dengan mengikuti prinsip-prinsip dasar pelatihan yang tepat.

Nala (1998: 75) menyatakan,

Pelatihan down the line drill adalah salah satu bentuk pelatihan yang termasuk dalam jenis pelatihan lari 
rintang (obstacle race). Dalam pelatihan down the line drill banyak menggabungkan unsur-unsur kecepatan dan kemampuan merubah arah dengan cepat setiap tiba pada satu garis menuju garis berikutnya dan seterusnya. Pelatihan down the line drill dilakukan dengan berlari secepatnya dan diubah kecepatan serta arahnya sesuai aba-aba "maju, mundur, kesamping kiri atau kanan" saat sampai pada satu garis sebelum melanjutkan ke garis berikutnya, dimana dilapangan ada beberapa garis berjejer berjarak 5 meter.

kelincahan. Dengan kata lain latihan kelincahan dapat meningkatkan

kemampuan siswa dalam dalam menggiring bola.

\section{SIMPULAN}

Berdasarkan hasil penelitian, analisis data dan pembahasan ternyata hipotesis penelitian yang diajukan dapat diterima, maka dengan demikian dapat diperoleh simpulan sebagai berikut:

1) Pelatihan down the line drill berpengaruh secara signifikan terhadap peningkatan kelincahan pada siswa putra kelas VII SMP Negeri 2 Sawan.

2) Pelatihan down the line drill berpengaruh secara signifikan terhadap peningkatan power otot tungkai pada siswa putra kelas VII SMP Negeri 2 Sawan.

\section{DAFTAR RUJUKAN}

Hardiyanti, (2013). "Efektifitas Latihan Hexagon Drill dan

Zig-Zag Run Terhadap Kelincahan Atlet Bulutangkis Putri Usia 10-12 Tahun di PB. PWS dan PB pancing Sleman"

Hidayat, Syarif. 2011. Teori dan Metodologi Latihan Olahraga Pariwisata I. (tidak diterbitkan)
Singaraja : Universitas

Pendidikan Ganesha.

Himawan Wismanadi (2010) dalam jurnal yang berjudul Pengaruh Pelatihan Plyometrik Rim Jump Dan Hexagon Drill Terhadap Peningkatan Daya Ledak Otot Tungkai

Kanca, 2006. Buku Ajar Metodologi Penelitian Kolahragaan. Singaraja: Jurusan Ilmu Keolahragaan Fakultas Olahraga dan Kesehatan Universitas Pendidikan Ganesha.

Nala,1998. Pelatihan Fisik Olahraga. Denpasar : UNUD.

Widiastuti, 2011. Tes Dan Pengukuran Olahraga. Jakarta: PT. Bumi Timur Jaya.

Yoda, I Ketut. 2006. Peningkatan Kondisi Fisik. (tidak diterbitkan) Singaraja : Jurusan IImu Keolahragaan: Universitas Pendidikan Ganesha. 